\title{
Occurrence of Paratanaisia confusa Freitas, 1951 in free-living guira cuckoo (Guira guira, Cuculiformes: Crotophagidae)
}

\author{
Ocorrência de Paratanaisia confusa Freitas, 1951 em anu-branco de vida livre \\ (Guira guira, Cuculiformes: Crotophagidae) \\ Mariele de Santi ${ }^{1}$; Marcos Rogério André ${ }^{1}$ Estevam Guilherme Lux Hoppe ${ }^{2}$; Karin Werther ${ }^{1 *}$

\begin{abstract}
${ }^{1}$ Laboratório de Imunoparasitologia, Departamento de Patologia Veterinária, Faculdade de Ciências Agrárias e Veterinárias, Universidade Estadual Paulista - UNESP, Jaboticabal, SP, Brasil

${ }^{2}$ Laboratório de Enfermidades Parasitárias dos Animais, Departamento de Medicina Veterinária Preventiva e Reproduçáo Animal, Faculdade de Ciências Agrárias e Veterinárias, Universidade Estadual Paulista - UNESP, Jaboticabal, SP, Brasil
\end{abstract}

Received December 6, 2016

Accepted February 9, 2017

\begin{abstract}
This report presents a description of natural infection of an adult free-living guira cuckoo with Paratanaisia confusa. Histological and morphological evaluations of renal and parasite samples were performed. The morphological analysis of the parasites revealed spiny tegument, characteristic of $P$. confusa helminthes. Although macroscopic alterations were absent in the kidneys, the histopathology revealed parasites inside the collecting ducts causing dilatation and destruction of the lining epithelial cells in addition to small focal inflammatory infiltrates in the renal parenchyma. However, as the bird was free-living and naturally infected it was not possible to confirm if all these alterations were directly caused by the parasite presence or if they were related to causes other than the parasitism. Nonetheless, such findings indicate that these trematodes may have pathogenic potential in this host.
\end{abstract}

Keywords: Histopathology, Trematoda, Digenea, Eucotylidae, new host record.

\section{Resumo}

A infecção de um anu-branco, de vida livre, por Paratanaisia confusa é descrita. Avaliações histológicas e morfológicas de amostras renais e dos parasitas foram realizadas. A análise morfológica dos parasitas revelou a presença de tegumento espinhoso, que é característico de P. confusa. Embora alteraçóes renais macroscópicas estivessem ausentes, a histopatologia revelou a presença de parasitas no interior de ductos coletores, provocando dilatação destes e destruição das células epiteliais, além de discretos infiltrados inflamatórios focais no parênquima renal. Entretanto, como a ave era proveniente de vida livre e naturalmente infectada, não foi possível confirmar se todas as alteraçóes observadas foram diretamente provocadas pela presença dos parasitas, ou se estavam relacionadas a outras causas. Todavia, esses achados indicam que os trematódeos dessa espécie possam ter potencial patogênico no hospedeiro estudado.

Palavras-chave: Histopatologia, Trematoda, Digenea, Eucotylidae, novo registro de hospedeiro.

The Eucotylidae digeneans of the genus Paratanaisia (Santos, 1934) Freitas 1959, are known parasites of the urinary tract of Neotropical birds, even though they are also found in other regions (MENEZES et al., 2001; LUPPI et al., 2007; UNWIN et al., 2012; ABDO \& SULTAN, 2013; PRASTOWO et al., 2014). Since the original description of these parasites, Paratanaisia have already been described affecting several bird species, including Columbiformes (TARODA et al., 2013; UNWIN et al., 2012; XAVIER et al., 2015), Galliformes (MENEZES et al., 2001; GOMES et al., 2005), Passeriformes (UNWIN et al., 2012; TAVELA et al., 2014),

*Corresponding author: Karin Werther. Laboratório de Imunoparasitologia, Departamento de Patologia Veterinária, Faculdade de Ciências Agrárias e Veterinárias, Universidade Estadual Paulista - UNESP, Via de Acesso Prof. Paulo Donato Castellane, s/n, Bairro Rural, CEP 14884-900, Jaboticabal, SP, Brasil. e-mail: werther@fcav.unesp.br
Psittaciformes (LUPPI et al., 2007), Tinamiformes (MAPELI et al., 2003; MOMO \& WERTHER, 2013; MOMO et al., 2016), and Ciconiiformes (ABDO \& SULTAN, 2013), suggesting low parasitic specificity.

The Paratanaisia genus comprises three species: Paratanaisia bragai (Santos 1934) Freitas 1959, Paratanaisia robusta (FREITAS, 1951), and Paratanaisia confusa (FREITAS, 1951). The three species have similar morphological and morphometrical features (TRAVASSOS et al., 1969). However, Freitas (1951) states that the tegument covering is an important morphological characteristic with diagnostic value, as $P$. robusta and $P$ bragai have scaly teguments (TRAVASSOS et al., 1969; BRANDOLINI \& AMATO, 2007), while $P$. confusa presents spiny tegument (TRAVASSOS et al., 1969).

The birds acquire the infection feeding on mollusks infected with metacercariae, the parasite infective form. In Brazil 
Leptinaria unilamellata (KELLER \& ARAÚJO, 1992) and Subulina octona (BRANDOLINI \& AMATO, 2006) were reported as intermediate hosts for Paratanaisia species. The effects of the infection by this digenean on the host are variable, ranging from unspecific or irrelevant alterations (PINTO et al., 2004; GOMES et al., 2005) to evident clinical signs with significant macroscopic changes (ABDO \& SULTAN, 2013). Microscopically, the dilation of renal collecting ducts with morphological alterations and abundant inflammatory reaction have been described (MENEZES et al., 2001; MAPELI et al., 2003; GOMES et al., 2005).

This report presents a description of natural infection by $P$. confusa in a free-living guira cuckoo and describes the associated pathological alterations.

The bird was attended at the Veterinary Hospital "Governador Laudo Natel”, from Universidade Estadual Paulista (Unesp), Faculdade de Ciências Agrárias e Veterinárias, Jaboticabal campus, SP, Brazil. The physical examination revealed poor body condition, apathy and hypothermia. Although the bird received clinical support therapy, it died the next day and was necropsied. A range of tissues samples were collected and fixed in $10 \%$ buffered formalin for $24 \mathrm{~h}$. Soon after, this material was embedded in paraffin, cut into 4- $\mu \mathrm{m}$ section, mounted on slides, stained with hematoxylin and eosin (JECKEL, 2007) and analyzed by light microscopy. Images were obtained with an Olympus BX-51 light microscope and processed with Image Pro Plus v. 4.0.

The remaining renal tissue was sliced and evaluated under stereoscopic microscope for parasite collection. The parasites were stored in vials with Railliet \& Henry solution (92\% deionized distilled water, $5 \%$ commercial formaldehyde and $3 \%$ glacial acetic acid) for latter chloridric carmine staining according to Travassos (1950) and identification according to Travassos et al. (1969).

At post mortem examination, all the internal organs including the kidneys showed normal appearance, coloration and size. The histopathological analysis of the renal tissue revealed the presence of several adult trematodes inside the collecting ducts (Figure 1A).
The affected ducts were dilated, compressing the adjacent tissue, showing flattening and destruction of the lining epithelial cells (Figure 1B). Still, moderate diffuse tubular degeneration and moderate multifocal congestion of the blood vessels were found. Discrete agranulocytic inflammatory reaction was observed in the parenchyma but without direct relation to the parasitized ducts.

The morphological evaluation of the parasite revealed tegument covered with spines, presence of well-developed sub-terminal oral sucker, with muscular wider than long pharynx. Sinuous ceca were fused in the caudal end. There was post-bifurcal pre-ovarian genital pore. Small acetabulum was seen on the first third of the body. Testes were lobed, pre-equatorial and post-ovarian, mostly intracecal and located in the same zone. Pre-testicular irregularly shaped ovary was observed laterally displaced. Vitelaria extended from the bifurcal zone to the body end. Uterus was well developed and covered most of the body from the genital pore to the caudal end. There were ellipsoid brownish eggs (Figures 2A and 2B). The parasites were characterized as $P$. confusa mainly because their typical spiny tegument, not seen in other congeneric species, which have scales covering the tegument (TRAVASSOS et al., 1969; BRANDOLINI \& AMATO, 2007).

Most of the reports on avian natural infection by Paratanaisia refer to $P$. bragai or to undetermined species. Previously, $P$. confusa has been described in captive Rhynchotus rufescens (MAPELI et al., 2003; MOMO \& WERTHER, 2013) and free-living Zenaida auriculata (TARODA et al., 2013). Therefore, this is the first report of this digenean in Guira guira.

The absence of macroscopic renal alterations, also mentioned in previous reports (MENEZES et al., 2001; MAPELI et al., 2003; TAVELA et al., 2014), indicate that these are not common on Paratanaisia infections, even though alterations with variable degree of relevance were described in some host species (UNWIN et al., 2012; MOMO \& WERTHER, 2013). Microscopically, all the observed alterations in the morphology of the collecting ducts, leading to compression of adjacent tissue, as observed by other
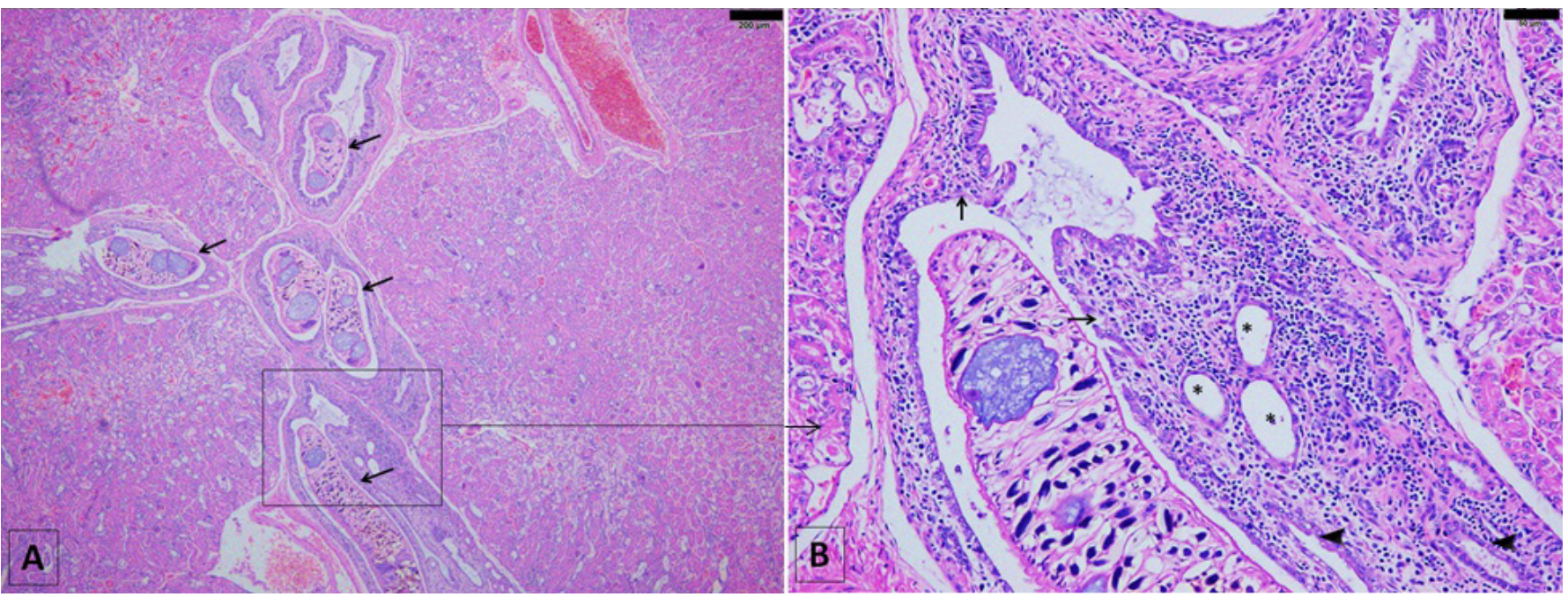

Figure 1. Photomicrography from guira cuckoo renal tissue. (A) Renal parasites in the collecting ducts (arrows) causing dilatation. Hematoxylin and eosin stain, scale $200 \mu \mathrm{m}$; (B) Magnification of selected area: Normal collecting ducts epithelium (arrowheads), flattening and destruction of the lining epithelial cells (arrows), dilated collecting ducts (asterisks). Hematoxylin and eosin stain, scale $50 \mu \mathrm{m}$. 

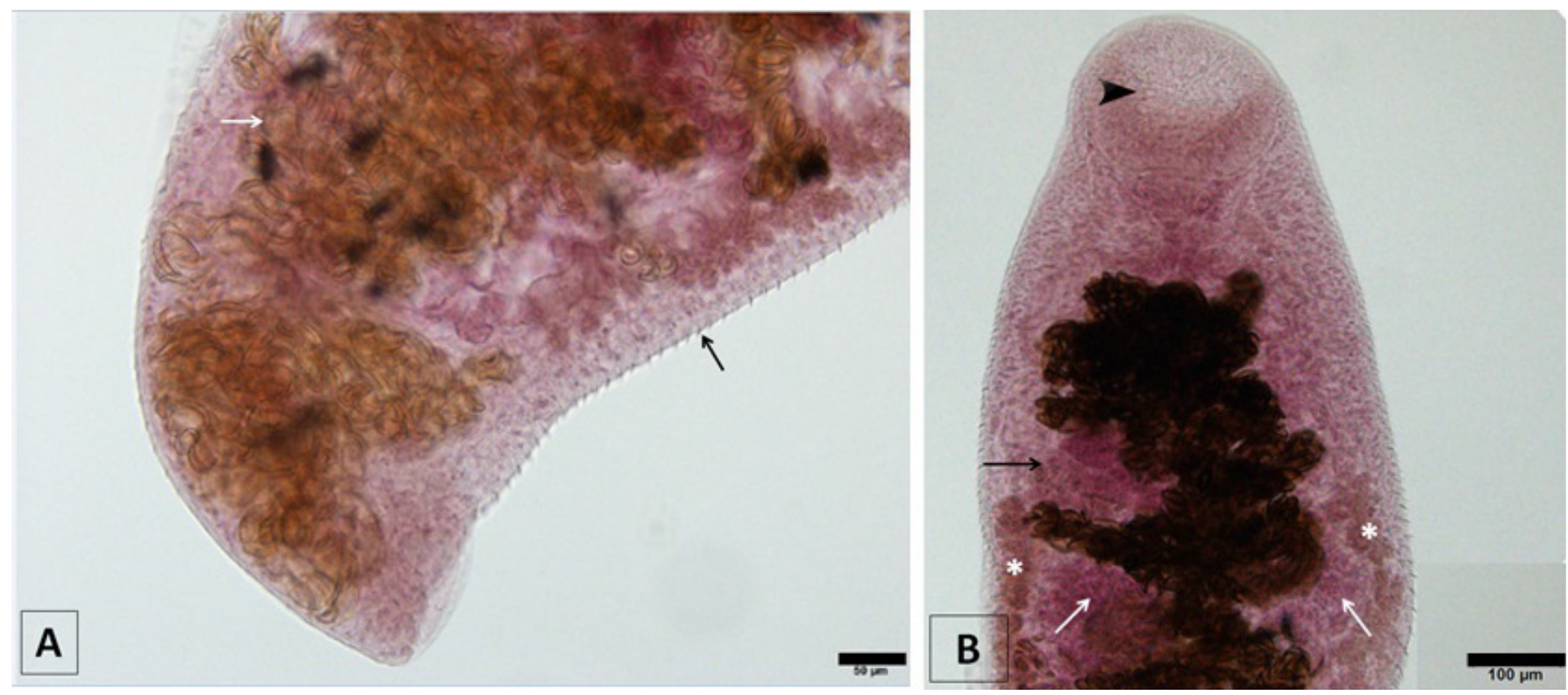

Figure 2. Photomicrography from guira cuckoo renal trematode Paratanaisia confusa. (A) Final portion of the trematode body showing ellipsoid brownish eggs (white arrow) and the tegument covered in spines (black arrow). Chloridric carmine stain, scale 50 $\mu \mathrm{m}$; (B) Initial portion of the trematode body evidencing well-developed sub-terminal oral sucker (arrowhead), pre-equatorial post-ovarian lobed testes (white arrows), pre-testicular irregularly shaped ovary (black arrow) and vitelaria (asterisks). Chloridric carmine stain, scale $100 \mu \mathrm{m}$.

authors (PINTO et al., 2004; GOMES et al., 2005; UNWIN et al., 2012; TAVELA et al., 2014), were probably caused by direct action of the parasites because their relatively large body size may result in physical compression.

This compression may even lead to alterations in non-parasitized ducts, such as decrease in lumen diameter or replacement by connective tissue, as reported for Paradisaea rubra (UNWIN et al., 2012) and Estrilda astrild (TAVELA et al., 2014) infected by P. bragai. Therefore, the parasitism could play an important role in inducing secondary renal lesions. The partial or complete obstruction of the collecting ducts could occur due to the parasites presence or cellular debris. This would decrease urine formation and elimination, which might predispose the host to visceral gout, as described in Rhynchotus rufescens infected by P. confusa (MOMO \& WERTHER, 2013; MOMO et al., 2016). In contrast, the dilation of the collecting ducts might be compensatory, therefore allowing the urine flow (PINTO et al., 2004).

While most previous studies indicate a relatively benign disease focused only in structures directly affected by the parasites (PINTO et al., 2004; BRENER et al., 2006; TAVELA et al., 2014), the bird from this report showed diffuse moderate tubular degeneration as well as discrete agranulocytic inflammatory reaction in the parenchyma of the cortical area of renal lobules. This indicates more severe kidney impairment and suggests that chronic infection could lead to renal deficiency. The relatively discrete alterations observed by other authors could be due to early onset of infection. However, as the bird was free-living and naturally infected it was not possible to confirm if all these alterations were directly caused by the parasite presence or if they were related to causes other than the parasitism, such as conditions of the host organism, nutritional state and concomitant infections.
In conclusion, the histopathological findings suggest that P. confusa might have pathogenic potential in Guira guira.

All applicable institutional guidelines for the care and use of animals were followed.

\section{Acknowledgements}

This work was supported by the National Counsel of Technological and Scientific Development - CNPq and São Paulo Research Foundation - FAPESP (Process nº 2015/22851-8).

\section{References}

Abdo W, Sultan K. Histopathological findings of the kidney Trematoda Paratanaisia spp. (Digenea: Eucotylidae) in cattle egret (Bubulcus ibis). Rev Bras Parasitol Vet 2013; 22(2): 312-313. PMid:23856732. http:// dx.doi.org/10.1590/S1984-29612013000200050.

Brandolini SVPB, Amato SB. Desenvolvimento larval de Paratanaisia bragai (Santos) (Digenea, Eucotylidae) sob condiçóes experimentais. Rev Bras Zool 2006; 23(4): 1097-1100. http://dx.doi.org/10.1590/S010181752006000400017.

Brandolini SVPB, Amato SB. Morfologia externa de espécimes adultos de Paratanaisia bragai (Santos, 1934) (Digenea: Eucotylidae). Rev Bras Parasitol Vet 2007; 16(3): 129-132. PMid:18078598. http://dx.doi. org/10.1590/S1984-29612007000300003.

Brener B, Tortelly R, Menezes RC, Muniz-Pereira LC, Pinto RM. Prevalence and pathology of the nematode Heterakis gallinarum, the trematode Paratanaisia bragai, and the protozoan Histomonas meleagridis in the turkey, Meleagris gallopavo. Mem Inst Oswaldo Cruz 2006; 101(6): 677-681. PMid:17072483. http://dx.doi.org/10.1590/S0074-02762006000600017. 
Freitas JFT. Revisão da família Eucotylidae Skrjabin, 1924 (Trematoda). Mem Inst Oswaldo Cruz 1951; 49(1): 33-271. PMid:14890534. http:// dx.doi.org/10.1590/S0074-02761951000100003.

Gomes DC, Menezes RC, Tortelly R, Pinto RM. Pathology and first occurrence of the kidney trematode Paratanaisia bragai (Santos, 1934) Freitas, 1959 (Digenea: Eucotylidae) in Phasianus colchicus L., 1758, from Brazil. Mem Inst Oswaldo Cruz 2005; 100(3): 285-288. PMid:16113870. http://dx.doi.org/10.1590/S0074-02762005000300013.

Jeckel EA No. Técnicas de rotina em histologia. In: Carli GA. Parasitologia clínica: seleção de métodos e técnicas de laboratório para o diagnóstico das parasitoses humanas. 2nd ed. São Paulo: Atheneu; 2007. p. 593-608.

Keller DG, Araujo JLB. Ciclo evolutivo de Paratanaisia bragai (Santos, 1934) (Trematoda, Eucotylidae) com novo hospedeiro intermediário no Brasil: Leptinaria unilamellata (D’Orbigny, 1835) (Gastropoda, Pulmonata, Subulinidae) em condições de laboratório. Rev Bras Parasitol Vet 1992; 1(2): 89-92.

Luppi MM, Melo AL, Motta ROC, Malta MCC, Gardiner CH, Santos LR. Granulomatous nephritis in psittacines associated with parasitism by the trematode Paratanaisia spp. Vet Parasitol 2007; 146(3-4): 363366. PMid:17418949. http://dx.doi.org/10.1016/j.vetpar.2007.03.011.

Mapeli EB, Nascimento AA, Szabó MPJ, Tebaldi JH. Infecçôes naturais por helmintos em perdizes (Rhynchotus rufescens Temminck, 1815) de cativeiro, no município de Jaboticabal, estado de São Paulo. Arq Inst Biol 2003; 70(4): 415-418.

Menezes RC, Mattos DG Jr, Gomes DC, Tortelly R, Muniz-Pereira LC, Pinto RM. Trematodes of free range reared guinea fowls (Numida meleagris Linnaeus, 1758) in the state of Rio de Janeiro, Brazil: Morphology and pathology. Avian Pathol 2001; 30(3): 209-214. PMid:19184902. http:// dx.doi.org/10.1080/03079450124448.

Momo C, Garrido E, Werther K. Anatomopathological findings in captive-raised red-winged tinamou (Rhynchotus rufescens). BrazJ Vet Res Anim Sci 2016; 53(3): 227-234. http://dx.doi.org/10.11606/issn.16784456.v53i3p227-234.
Momo C, Werther K. Parasitismo renal em perdizes (Rhynchotus rufescens) criadas em cativeiro. PUBVET 2013; 7(16): 1-8. http://dx.doi. org/10.22256/pubvet.v7n16.1578.

Pinto RM, Menezes RC, Tortelly R. Systematic and pathologic study of Paratanaisia bragai (Santos, 1934) Freitas, 1959 (Digenea, Eucotylidae) infestation in ruddy ground dove Columbina talpacoti (Temminck, 1811). Arq Bras Med Vet Zootec 2004; 56(4): 472-479. http://dx.doi. org/10.1590/S0102-09352004000400008.

Prastowo J, Sahara A, Marganings C, Ariyadi B. Identification of renal parasite and its blood urea-creatinine profile on the Indonesian indigenous pigeons. Int J Poult Sci 2014; 13(7): 385-389. http://dx.doi.org/10.3923/ ijps.2014.385.389.

Taroda A, Barros LD, Zulpo DL, Cunha IAL, Paiva MCDC, Sammi AS, et al. Occurrence of gastrointestinal and renal helminths in Zenaida auriculata (Des Murs, 1847) trap-captured from Brazil. Rev Bras Parasitol Vet 2013; 22(3): 415-419. PMid:24142175. http://dx.doi.org/10.1590/ S1984-29612013000300016.

Tavela AO, Carreta M Jr, Oliveira AR, Carneiro FT, Silva VHD, Braga FR, et al. Parasitism by Paratanaisia bragai (Digenea, Eucotylidae) in commom waxbill (Estrilda astrild). Arq Bras Med Vet Zootec 2014; 66(4): 1276-1280. http://dx.doi.org/10.1590/1678-7136.

Travassos L, Freitas JFT, Kohn A. Gênero Paratanaisia Freitas, 1959. Mem Inst Oswaldo Cruz 1969; 67: 340-343.

Travassos L. Introdução ao estudo da helmintologia. BrazJ Biol 1950: 173.

Unwin S, Chantrey J, Chatterton J, Aldhoun JA, Littlewood DTJ. Renal trematode infection due to Paratanaisia bragai in zoo housed Columbiformes and a red bird-of-paradise (Paradisaea rubra). Int J Parasitol Parasites Wildl 2012; 2(2): 32-41. PMid:24533313. http:// dx.doi.org/10.1016/j.ijppaw.2012.11.001.

Xavier VB, Oliveira-Menezes A, Santos MAJ, Amato SB, Torres EJL, Pinheiro J, et al. Histopathological changes in the kidneys of vertebrate hosts infected naturally and experimentally with Paratanaisia bragai (Trematoda, Digenea). Rev Bras Parasitol Vet 2015; 24(2): 241-246. PMid:26154968. http://dx.doi.org/10.1590/S1984-29612015017. 